\title{
Ichthyoplankton seasonality in the Gulf of Salamanca, Colombian Caribbean Sea
}

\author{
Estacionalidad del ictioplancton en el Golfo de Salamanca, Caribe Colombiano
}

\author{
Camilo B. García*
}

\begin{abstract}
The identity, density and spatial and temporal distribution of fish larvae and eggs were investigated in the Gulf of Salamanca, Colombian Caribbean. A total of 49 stations chosen randomly and distributed among the rainy and dry seasons were visited. Due to scarcity of previous studies taxonomic level was restricted to families. Twenty-six fish families were identified and two more could not be identified. Kruskal-Wallis one-way analysis of variance, non-metric multidimensional scaling and Bio-Env analysis were used to test hypotheses and search for patterns. Fish larvae and eggs have a patchy spatial distribution. Temporal distribution suggests a definite influence of seasonality on fish larvae assemblages with the transition time into the dry season (December) correlating to the highest abundance in numbers and biomass of fish larvae and eggs.
\end{abstract}

Keywords: Ichthyofauna, fish eggs, fish larvae, assemblages, Caribbean Sea, spatial-temporal distribution

\section{Resumen}

Se investigó la identidad. densidad y distribución especial y temporal de larvas y huevos de peces en el Golfo de Salamanca, Caribe Colombiano. Se visitó un total de 49 estaciones escogidas aleatoriamente y repartidas entre las épocas de lluvia y seca. En razón a la escasez de estudios previos el nivel taxonómico se restringió a familia. En total se identificaron 27 familias más dos que no pudieron ser identificadas. Se usaron análisis de varianza Kruskal-Wallis de una vía, escalamiento no métrico multidimensional y el análisis Bio-Env para probar hipótesis y buscar patrones. Las larvas y los huevos de peces tienen una distribución espacial por parches. La distribución temporal sugiere que hay una influencia definida de la estacionalidad sobre los ensamblajes de larvas de peces de modo que el periodo de transición (diciembre) hacia la época seca correlaciona con las mayores abundancias en número y biomasa de larvas y huevos de peces.

Palabras claves: Ictiofauna, huevos de peces, larvas de peces, ensamblajes, Mar Caribe, distribución espacio-temporal 


\section{INTRODUCTION}

Despite its importance in basic biology studies and management of fish resources the study of ichthyoplankton in the Colombian Caribbean Sea has not advanced very much. Apart from some local studies scattered in time and space, few general work can be cited. Thus Manjarrés et al. (2005) present results of surveys covering the complete neritic zone of the Colombian Caribbean while Medellín-Mora et al. (2013) present a taxonomic checklist of fish larvae recorded for the Colombian Caribbean. Few studies have follow the presence of fish larvae in time (Arteaga et al. 2004, Correa-Herrera et al. 2017, Gallego and Giraldo 2018).

In this study the presence and abundance of fish larvae and eggs in year 1996 is presented for the Gulf of Salamanca, Colombia Caribbean Sea. The value of rescuing this rather old data lies in documenting a past situation in order to have a point of comparison with more recent studies, should they be conducted.

As climate in the study area is bimodal with a dry season associated to the trade winds and resulting up-welling from December-January to April and a rainy season from May to November (García et al. 2013), the study presented here seeks to answer the question whether there is a correlation between climate seasonality and presence of fish larvae (at family level) and eggs.

\section{MATERIALS AND METHODS}

Four cruises were conducted. Two in the dry season (March and April, 18 hauls), one in the rainy season (August, 20 hauls) and one in the transition period (December, 11 hauls) in 1996. The August cruise took place in what is call the "Veranillo de San Juan" (July-August). a short period when wind speed slightly increases but not to the levels of the dry season proper (García et al. 2013). Thus that cruise is treated here as representing the rainy season.

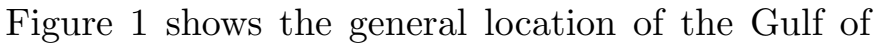
Salamanca and the position of sampling stations.
Stations were chosen at random. A total of 49 stations were visited and parallel with plankton hauls oceanographic data were taken by means of a CTD probe.

Conic nets were used with mesh size $500 \mu \mathrm{m}$. A calibrated flowmeter was attached to the nets in order to estimate water volume sampled. Hauls lasted around 10 minutes and were conducted horizontally. Samples were preserved in the field with $4 \%$ formaldehyde and translated to a solution of 30\% alcohol and 10\% formaldehyde in the lab.

Abundance data were standardized to $\mathrm{m}^{3}$ by the formula:

$$
c=\frac{N \cdot 100}{\pi \cdot r^{2} \cdot d}
$$

Where:

$c=$ number of individuals or biomass in $100 \mathrm{~m}^{3}$

$N=$ number of individual in the haul

$\pi \cdot r^{2} \cdot d=$ water volume filtered

$r=$ net mouth radius

$d=$ flowmeter revolutions multiplied by de calibration factor

Wet biomass per $100 \mathrm{~m}^{3}$ were estimated by means of an analytical balance $( \pm 0.1 \mathrm{mg})$.

Taxonomic identification to family level was done with the help of Ditty and Shaw (1994), Fahay (1983), Farooqi et al. (1995), González (1996), Moser (1996), Olivar and Fortuño (1991), among others. To date no local guide of early stages of fishes exists for the Colombian Caribbean.

Differences in biomass and density of fish larvae and eggs and richness (fish families) were tested with climate seasons and the transition period (December cruise) as categories. Non parametrical analysis of variance (Kruskal-Wallis test) were conducted as data were not normally distributed nor the homoscedasticity assumption met. Two sample test were conducted with the Kolmogorov-Smirnov test. Significance was set at $p<0.05$. A non-metric multidimensional scaling ordination (MDS) on fish larvae density was used to depict general spatial-temporal relations among hauls (Bray-Curtis distance). These 

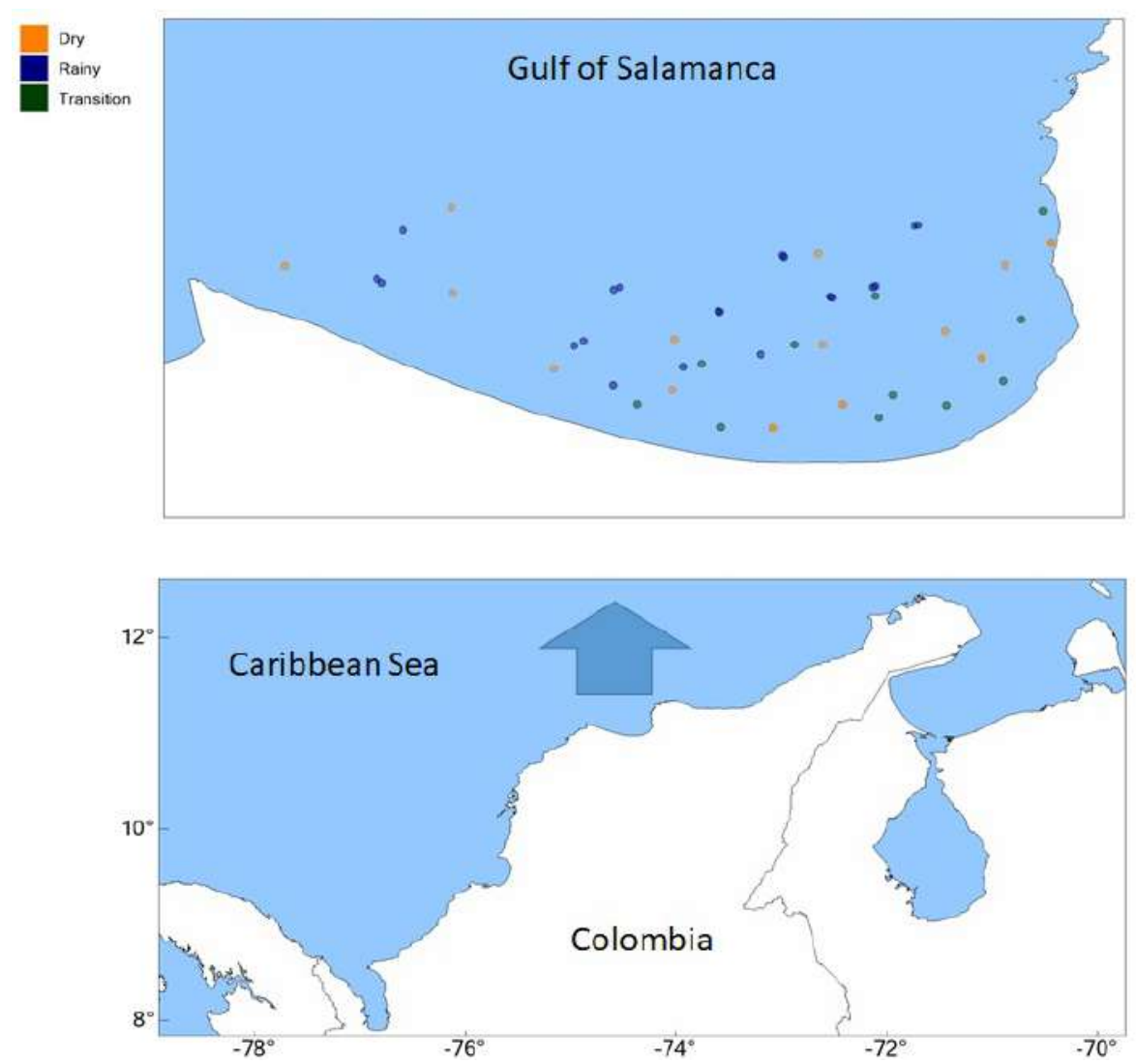

Figura 1. Position of the Gulf of Salamanca with respect to the Colombian Caribbean. Location of haul stations is shown in different colors according to climate season.

analyses were performed with the application RWizard (Guisande et al. 2014). Further, association between presence of fish larvae and oceanographic features was tested via a Bio-Env test (Clarke and Ainsworth 1993) as implemented in the $\mathrm{R}$ package vegan (Oksanen et al. 2018).

\section{RESULTS}

Twenty-eight families were present in the hauls, including two not identified families (table 1). Serranidae and Lutjanidae were the most abundant families but not the most frequent with that position occupied by Engraulidae. Sciaenidae and the two unidentified families (table 1). Most families were scarce and infrequent (table 1$)$.

Mean larvae biomass was different between seasons (Kruskal-Wallis test. $p<0.05$ ). Kolmogorov-
Smirnov two sample test revealed differences in all comparisons $(p<0.05)$ with mean larvae biomass increasing from the dry season to the transition time as defined above (figure 2). In contrast, mean larvae density showed no differences between season (Kruskal-Wallis test, $p>0.05$, figure B).

Mean egg biomass was different between seasons (Kruskal-Wallis test, $p<0.05$ ). KolmogorovSmirnov two sample test revealed differences in the comparisons with the transition time $(p<0.05)$ but only marginal in the comparison between dry and rainy season ( $p=0.07$, figure $\mathbb{G}$ ). Mean egg density was different between seasons (Kruskal- Wallis test, $p<0.05)$. Kolmogorov-Smirnov two sample test revealed differences in all comparisons $(p<0.05)$ with mean egg density decreasing from the transition time to the rainy season (figure 5 ). 


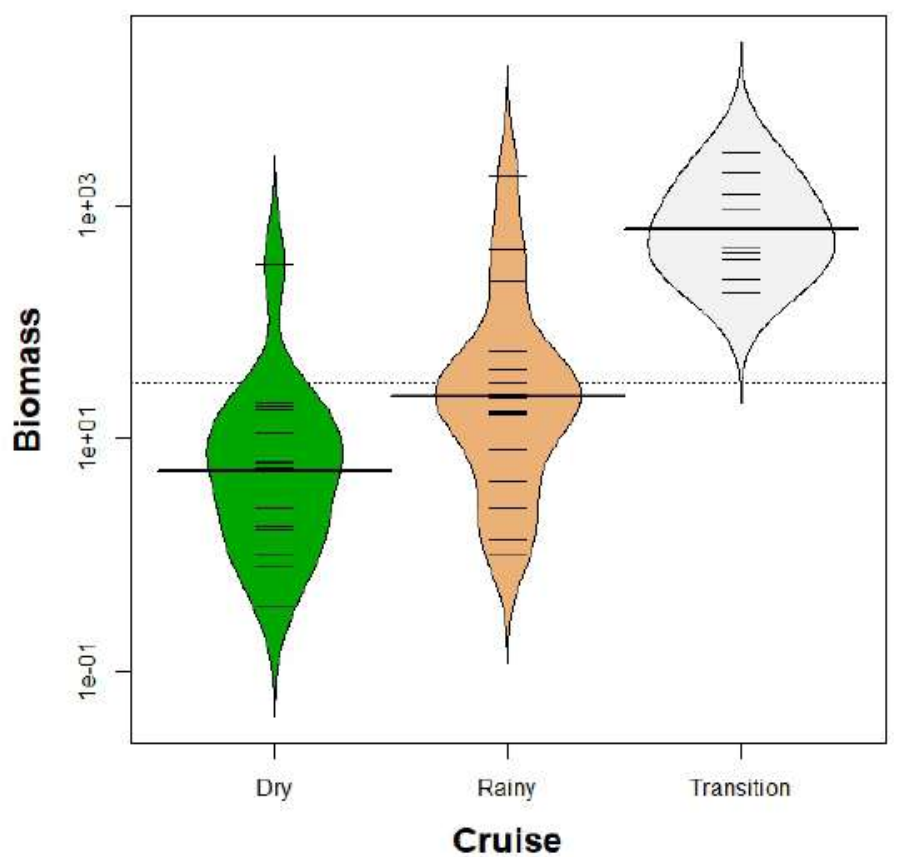

Figure 2. Beanplot of fish larvae biomass $\left(\mathrm{mg}\right.$ per $100 \mathrm{~m}^{3}$ ) in the Gulf of Salamanca, Colombian Caribbean, according to climate seasons.

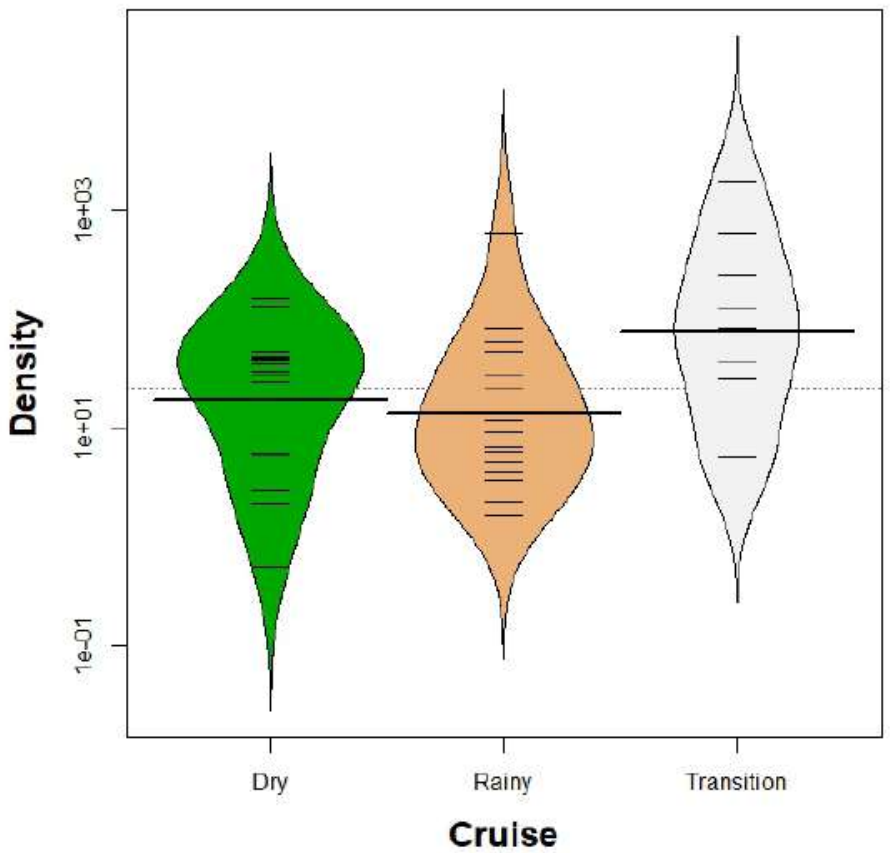

Figure 3. Beanplot of fish larvae density (number per $100 \mathrm{~m}^{3}$ ) in the Gulf of Salamanca, Colombian Caribbean, according to climate seasons. 
Table 1. Fish larvae families ordered according to accumulated density (individuals per $100 \mathrm{~m}^{3}$ ) in the Gulf of Salamanca, Colombian Caribbean, after four cruises in 1996.

\begin{tabular}{lcc}
\hline Family & $\begin{array}{c}\text { Acccumulated } \\
\text { density }\end{array}$ & $\begin{array}{c}\text { Frequency } \\
\text { in hauls }\end{array}$ \\
\hline Serranidae & 2037.2 & 3 \\
Lutjanidae & 572.7 & 2 \\
Gobiidae & 477.2 & 8 \\
\hline Engraulidae & 329.2 & 16 \\
Family 1 & 314.4 & 17 \\
Family 2 & 226.2 & 19 \\
Sciaenidae & 123.8 & 12 \\
Clupeidae & 113.0 & 6 \\
Gonostomatidae & 73.7 & 4 \\
Myctophidae & 67.0 & 10 \\
Bregmacerotidae & 53.9 & 7 \\
Acanthuridae & 27.8 & 1 \\
Ophichthidae & 17.6 & 2 \\
Paralichthyidae & 16.9 & 4 \\
Scorpaenidae & 13.3 & 2 \\
Blenniidae & 8.5 & 2 \\
Carangidae & 8.0 & 3 \\
Exocoetidae & 6.4 & 1 \\
Scopelarchidae & 6.4 & 1 \\
Ophidiidae & 2.9 & 1 \\
Scombridae & 2.8 & 1 \\
Phosichthyidae & 2.8 & 1 \\
Microdesmidae & 2.7 & 1 \\
Labridae & 2.3 & 1 \\
Bothidae & 1.5 & 1 \\
Synodontidae & 1.5 & 1 \\
Tetraodontidae & 1.1 & \\
Priacanthidae & 0.5 & 1 \\
\hline & & 1 \\
\hline & & 1 \\
\hline
\end{tabular}

Mean family richness was not different between seasons (Kruskal-Wallis test, $p>0.05$, figure 6 ). The Bio-Env analysis showed season as the environmental variable with the highest correlation with community data (Spearman index, 0.37). Combinations of environmental variables (temperature, salinity and time of hauling) showed smaller correlations. Figure $\square$ shows the MDS based on density (stress $=0.034$ ). As can be seen transition time hauls were only marginally intermingled with the other hauls while hauls in the dry and rainy season mix, although hauls in the rainy season show more dispersion than hauls in the dry season (figure $\square$ ).

\section{DISCUSSION}

A pattern emerges from the analysis: the transition period into the dry season (December) departs from the other two, the dry and the rainy seasons. In terms of sea surface temperature and salinity the transition period shows the highest anomaly in relation with the rest of the year (figure $\mathbf{8}$ ). This finding suggest that the period of rapidly decreasing sea surface temperatures and rapidly increasing salinity and wind speed (García et al. 2013) might function as an environmental cue for enhanced fish eggs and larvae presence in the waters of the Gulf of Salamanca. Thus, biomass and density of both larvae and eggs is higher in the transition period than elsewhere (figures 2 to 5) and in several instances, statistically so.

Family richness, on the other hand, appears not to be affected by the alternation of seasons and in fact fish larvae and eggs were found in all cruises (but not in all hauls) suggesting continuous reproduction of fishes the year round but with a peak as discussed above. Because presence in the hauls was so patchy (table 1) it is not possible to assign definite presence times for the different fish families. i.e. the species in the families of known occurrence in the Gulf of Salamanca (García and Armenteras 2015).

The Gulf of Salamanca is not homogenous in terms of its oceanography. García et al. (2013) distinguish three sectors, one to the east influenced by freshwater inputs from the coastal lagoon Ciénaga Grande de Santa Marta and rivers Córdoba and Toribio but restricted in the transition time and dry season to a narrow strip against the coast by action of the trade winds. A central sector with permanent intrusion of oceanic waters and a west sector with intrusion of fresh water from the Magdalena river and where this water collides with oceanic waters. The frontiers and extension of these water masses change as the year progresses. The sampling design in this study did not include these oceanographic structures and results might be biased by undersampling of certain areas consequence of the simple random sampling schema used. Thus. it should be confirmed whether the enhanced presence of fish larvae and eggs in the transition period is a general feature in the Gulf of 


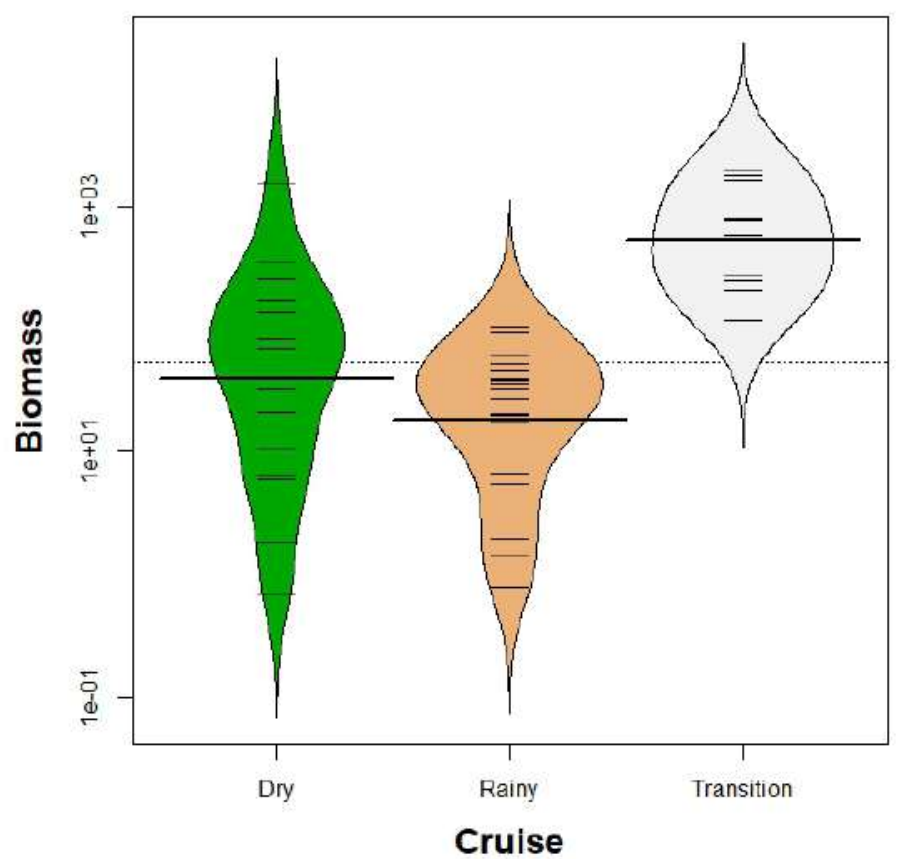

Figure 4. Beanplot of fish eggs biomass ( $\mathrm{mg}$ per $100 \mathrm{~m}^{3}$ ) in the Gulf of Salamanca, Colombian Caribbean, according to climate seasons.

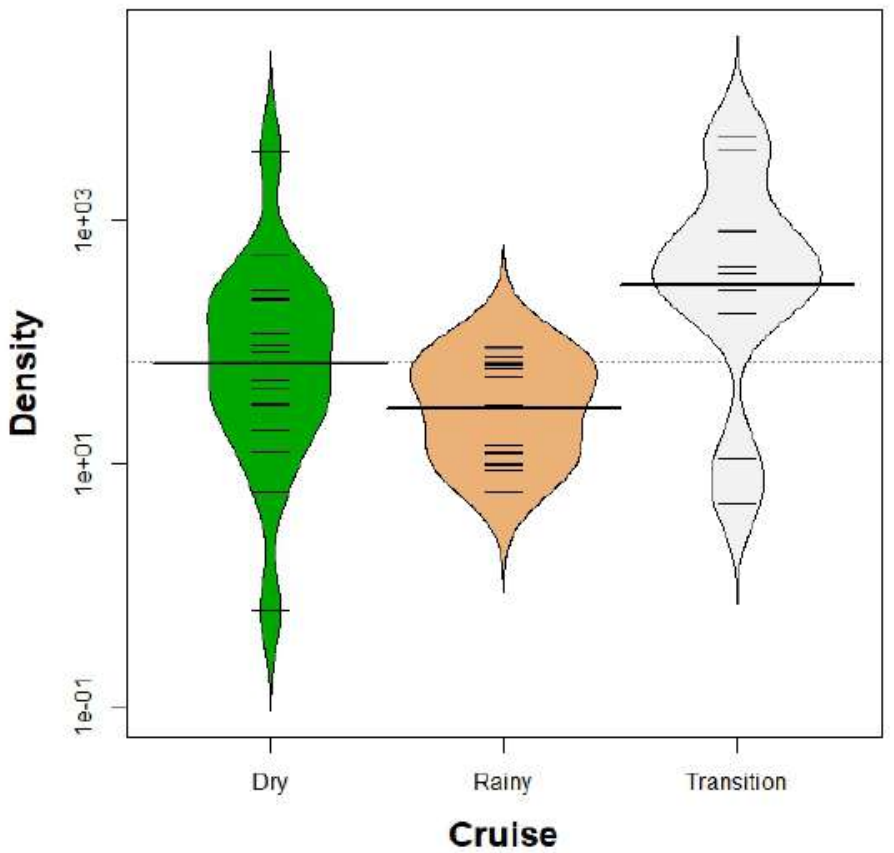

Figure 5. Beanplot of fish eggs density (numbers per $100 \mathrm{~m}^{3}$ ) in the Gulf of Salamanca, Colombian Caribbean, according to climate seasons. 


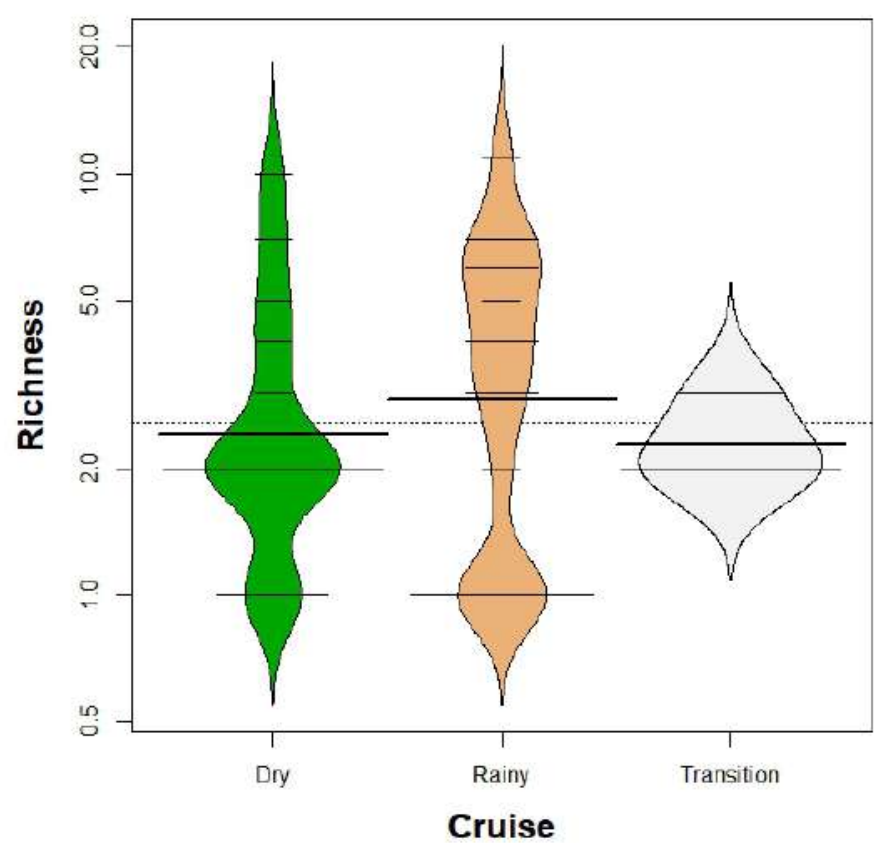

Figure 6. Beanplot of fish larvae family richness in the Gulf of Salamanca, Colombian Caribbean, according to climate seasons.

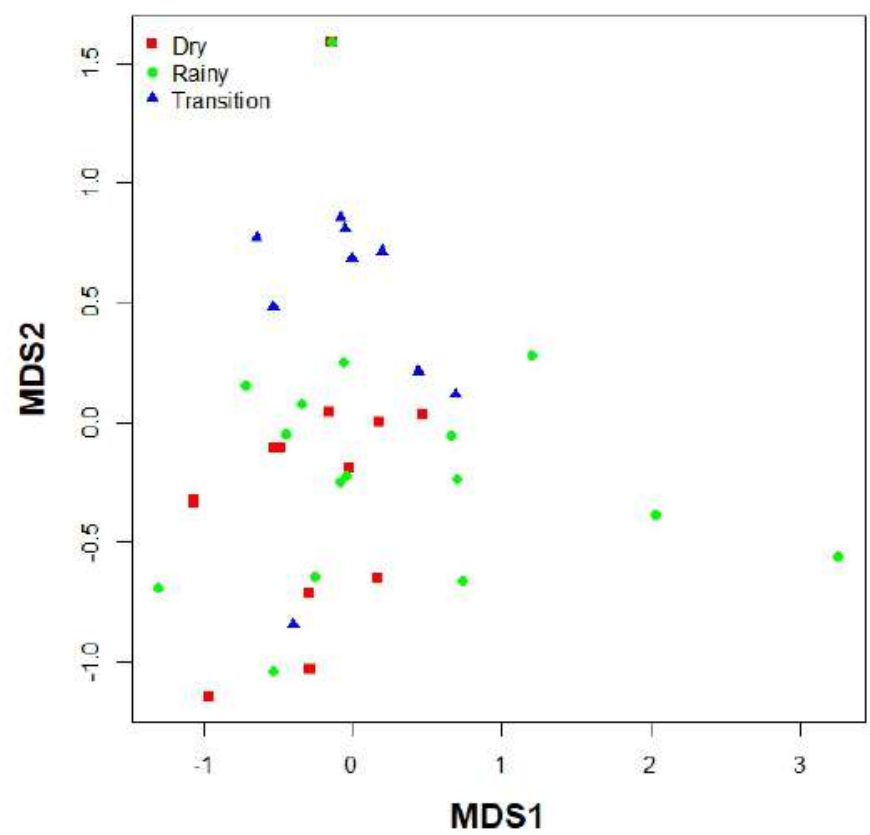

Figure 7. Non metrical multidimensional scaling (MDS) plot showing the relative positions of ichthyoplankton haul stations in the Gulf of Salamanca, Colombian Caribbean, according to climate season. Bray-Curtis distance for fish larvae families density. 
Salamanca.

As mentioned above, Arteaga et al. (2004) followed the presence and abundance of fish larvae of the family Lutjanidae in the north-east Colombian Caribbean (Guajira peninsula). The results here with respect to this family stand in contrast to theirs as Lutjanidae larvae in our hauls appeared only in the transition cruise (December) while they report maximal abundances in May, July and October, i.e.. the rainy season, when the highest sea surface temperature and lowest salinity were recorded. This is unexpected as the Gulf of Salamanca and the Guajira peninsula share the oceanographic feature of upwelling waters in the dry season (Andrade and Barton 2005. García et al. 2013). This discordance cannot be explained for the moment. More in line with results here are findings of Correa-Herrera et al. (2017) for estuarine areas in the Gulf of Urabá, far to the south-west of the Gulf of Salamanca, who found that fish larvae were more abundant in the dry season. On the other hand, Correa-Herrera et al.
(2017) found eggs mostly in the rainy season while here eggs were found in all cruises and most abundant both in numbers and biomass in the transition time into the dry season (December). The waters explored by Correa-Herrera et al. (2017) are estuarine in nature, thus there may lay an explanation but further research is needed in order to understand these coincidences or the lack of them.

Gallego and Giraldo (2018) sampled fish larvae in July and November in Bahia Portete, a semi-enclosed bay to the northeast of the Gulf of Salamanca in the Guajira peninsula. These authors consider July as representative of the dry season and November as representative of the rainy season. July rather correspond to the short period called Veranillo de San Juan (July-August) as explained to above, than to the dry season proper. They found a higher abundance of fish larvae in July than in November which is somewhat in line with finding in this work with high abundances of larvae associated to conditions of high wind speed. But again, coincidences or lack of

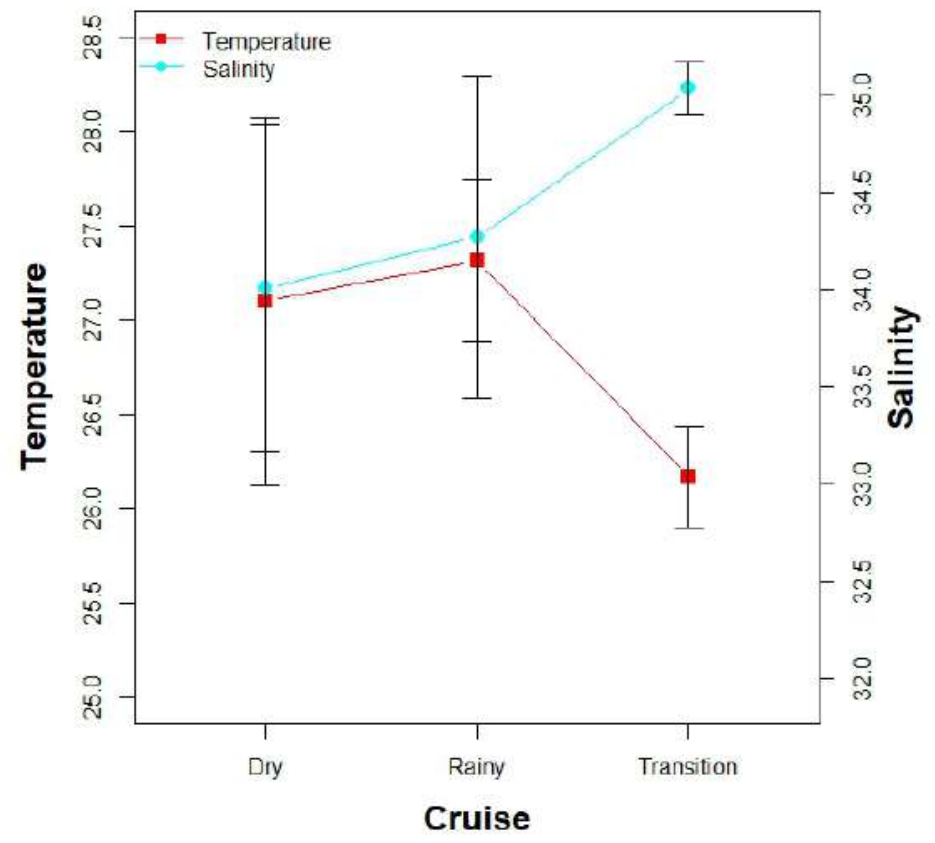

Figure 8. Line plot showing the behavior of sea surface temperature $\left({ }^{\circ} \mathrm{C}\right.$ ) and salinity (PSU) in the Gulf of Salamanca, Colombian Caribbean, according to climate seasons in year 1996. Mean values plus minus one standard deviation. 
them cannot be explained for the moment.

Indispensable future work should result in local taxonomic guides for fish larvae, if we are to understand fish spatial-temporal presence patterns as this knowledge may help design rules for fishing. for instance, time closures. The hypothesis emerging from this work as to enhanced presence of fish larvae and eggs in the Gulf of Salamanca related to rapid oceanographic changes in the transition period (December) into the dry season should be confirmed by more intensive surveys in space and time.

\section{ACKNOWLEDGEMENTS}

Ángela Buitrago conducted field and laboratory work. This research was financed by COLCIENCIAS grant number 2105-09-176-94. The support of Instituto de Investigaciones Marinas y Costeras. INVEMAR, is acknowledged. Comments by two anonymous reviewers helped to improve the manuscript.

\section{CONFLICTS OF INTEREST}

The author expresses that there is no conflict of interest.

\section{REFERENCES}

Andrade CA, Barton ED. 2005. The Guajira upwelling system. Continental Shelf Research 25: 10031022. doi.org/ 10.1016/j.csr.2004.12.012.

Arteaga E, Criales-Hernández MI, Altamar J, Manjarrés L. 2004. Distribución y abundancia de larvas de peces de la familia Lutjanidae en la zona nororiental del Caribe colombiano durante un ciclo anual (20002001). Ciencias Marinas 30(3): 381-390. http://dx.doi.org/10.7773/cm. v:30i:3.3:3.5.

Clarke KR, Ainsworth M. 1993. A method for linking multivariate community structure to environmental variables. Marine Ecology Progress Series 92: 205-219. doi: 10.3354/meps092205.

Correa-Herrera T, Barletta M, Lima ARA, Jiménez-Segura LF, Arango-Sánchez LB. 2017. Spatial distribution and seasonality of ichthyoplankton and anthropogenic debris in a river delta in the Caribbean Sea. Journal of Fish Biology 90: 13561387. doi:10.1111/jfb.13243.

Ditty JG, Shaw RF. 1994. Preliminary guide to the identification of the early life history stages of sciaenid fishes from the Western Central Atlantic. NOOA Technical
Memorandum. NMFS-SEFSC-349.118 p.

Fahay M. 1983. Guide to the early stages of marine fishes occurring in the western North Atlantic Ocean, Cape Hatteras to the southern Scotian shelf. Journal of Northwest Atlantic Fishery Science. 4:1-423. https://journal.nafo.int/Volumes/Articles/ID/14/catego ryId/4/Guide-to-the-Early-Stages-of-Marine-Fishesoccurring-in-the-Western-North-Atlantic-Ocean-CapeHatteras-to-the-Southern-Scotian-Shelf.

Farooqi T, Shaw RF, Ditty JG. 1995. Preliminary guide to the identification of the early life history stages of anchovies (Family Engraulidae) of the Western Central Atlantic. NOAA Tech. Memorandum. NMFS-SEFSC-358.65 p.

Gallego JJ, Giraldo A. 2018. Variación espacial y temporal de larvas de peces en una bahía hipersalina del Caribe colombiano. Boletín de Investigaciones Marinas y Costeras 47 (1): 117-141. doi: 10.25268/bimc.invemar. 20118.47 .1 .741$.

García CB, Duarte LO, Ramírez G. 2013. Fisiografía y oceanografía del golfo de Salamanca (mar Caribe. Colombia). En: LM Melgarejo, CB García editores. Investigación en Ciencias del Mar: Aportes de la Universidad Nacional de Colombia. Bogotá: Universidad Nacional de Colombia, Red de Estudios del Mundo Marino. p. 111140.

García CB, Armenteras D. 2015. Atlas de la ictiofauna demersal de fondos blandos del Caribe continental colombiano: Aproximación a su biodiversidad. Bogotá: Universidad Nacional de Colombia.

Guisande C, Heine J, González-DaCosta J, García-Roselló E. 2014. RWizard Software. University of Vigo. Vigo, Spain. http://www.ipez.es/rwizard.

González-Bencomo E. 1996. Larvas y juveniles de la costa oriental del lago de Maracaibo, Venezuela. Boletín del Centro de Investigaciones Biológicas. 30: (1) 45-76. http://produccioncientificaluz.org/index.php/ boletin/article/download/339/339.

Manjarrés L, Vergara A, Torres J, Rodríguez G, Arteaga E, Viaña J, Arévalo J, Galvis R. 2005. Evaluación de peces demersales e ictioplancton en el mar Caribe de Colombia, incluyendo condiciones oceanográficas. Revista Intropica 2: 51-86. http://revistas.unimagdalena.edu.co/index. $\mathrm{php} /$ intropica/article/view/45/43.

Medellín-Mora J, Polanco A, Navas G. 2013. Inventario de larvas de peces registradas para el Caribe colombiano. Boletín Investigaciones Marinas y Costeras 42(2): 233253. doi: 10.25268/bimc.invemar.2013.42.2.48.

Moser GH (Ed.). The early stages of fishes in the California Current region. CalCCOFI. Atlas No. 33.1517 p. http:// calcofi.org/publications/atlases/CalCOFI_Atlas_33.pdf.

Oksanen J, Guillaume Blanchet F, Friendly M, Kindt R, Legendre P, McGlinn D, Minchin PR, O'Hara RB, Simpson GL, Solymos P, Stevens MH, Szoecs E, Wagner H. 2018. vegan: Community Ecology Package. R package version 2.5-2. https://CRAN.R-project.org/package=vegan.

Olivar MP, Fortuño JM. 1991. Guide to the ichthyoplankton of the Southeast Atlantic(Benguela Current Region). Scientia Marina 55(1): 1-383. https://digital.csic.es/handle/ $10261 / 28659$. 